East African Medical Journal Vol. 81 No. 6 June 2004

IMPACT OF CHILD MORTALITY AND FERTILITY PREFERENCES ON FERTILITY STATUS IN RURAL ETHIOPIA

Y. Fitaw, MD, MPH, Assistant Professor of Public Health, Department of Community Health, Gondar College of Medical Sciences, Y. Berhane, MD, MPH, PhD, Professor of Epidemiology, Department of Community Health and A. Worku, BSc, MSc, PhD, Assistant Professor of Biostatistics, Medical Faculty, Department of Community Health, Addis Ababa University, P.O. Box 1176, Addis Ababa, Ethiopia

Request for reprints to: Dr. Y. Fitaw, Department of Community Health, Gondar College of Medical Sciences, P.O. Box 196, Gondar, Ethiopia

\title{
IMPACT OF CHILD MORTALITY AND FERTILITY PREFERENCES ON FERTILITY STATUS IN RURAL ETHIOPIA
}

\author{
Y. FITAW, Y. BERHANE and A. WORKU
}

\begin{abstract}
Objectives: To determine the effects of child mortality and fertility preference on fertility status in rural Ethiopia.

Design: Case-referent where the cases were women with number of children ever born alive was less than five and controls were women with number of children ever born alive greater or equal to five.

Setting: Butajira rural health project study base which is a field epidemiologic laboratory found $35 \mathrm{Kms}$ south of the capital city of Ethiopia, Addis Ababa run by the Department of Community Health of Tikur Anbessa Medical Faculty.

Main outcome measures: Fertility status measured by number of children ever born alive; death of a child or an infant is a predictor.

Subjects: A total of 219 women with number of children ever born alive less than five and 899 women with number of children ever born alive greater or equal to five were included in the study.

Results: Child mortality affected number of children ever born alive significantly (OR= 7.39, $95 \%$ CI: 4.62, 9.08). As the number of children died increased proportionally, there is a proportional increase in the risk of higher fertility $\left(X^{2}\right.$ for trend 4.92, d.f $=4$, $p$-value 0.02). Number of children desired before marriage, desire for more children and sex preference were not associated with increased fertility in this study. Of all the socio-demographic and reproductive variables, later age at first marriage and first birth showed lower number of children ever born alive with $(\mathrm{OR}=1.82,95 \% \mathrm{CI}$ : $1.24,2.83)$ and $(\mathrm{OR}=3.08,95 \% \mathrm{Cl}: 2.03,4.68)$ respectively. Breast-feeding duration of more than six months showed association with less number of children ever born alive $(\mathrm{OR}=1.92,95 \%$ CI: $1.30,2.80)$.

Conclusion: The study finding implies high fertility status is strongly associated with child death and hence measures that curb child mortality are believed to decrease fertility status besides promoting child survival.
\end{abstract}

\section{INTRODUCTION}

The demographic pattern of the developing countries is characterised by the co-existence of high fertility and high infant, and child mortality(1). Fertility in sub-Saharan Africa remains the highest of any region of the world(2). Studies in a number of countries indicated that wherever fertility is high, maternal, infant and child mortality are high(3).

There are two groups of factors that affect fertility. The first group consists of socioeconomic variables, which are termed as indirect determinants. The economic and cultural factors are included in this group. The direct knowns as intermediate determinants are biological and behavioural factors through which the indirect determinants must eat to affect fertility. Child and infant mortality is one of the intermediate factors known to affect fertility(4).
Ethiopia is one of the populous countries in Africa. It stands third after Nigeria and Egypt. According to the 1994 census, the projected estimate for the year 2001 was 65.3 million with an annual growth rate of $2.6 \%$. The total fertility rate for the year 2000 was found to be 5.9 according to the demographic and health survey(6). The Crude Birth Rate (CBR) of 44.17 per 1000 population and Crude Death Rate (CDR) of 14.96 per 1000 population was estimated for the year 2000. If the population continues to grow at this rate, the population of Ethiopia is expected to double in less than 23 years(7). The use of contraception in Ethiopia is low about $8 \%$ for currently married women, which is low to affect the fertility level significantly(6). Maternal mortality ratio (MMR) is estimated at $560-850$ per 100,000 live births(8). 
Ethiopia and other similarly developing countries, which have developed formal programmes to bring down the level of fertility, are finding that the greatest obstacle in the way of their implementation derives from the persistently high level of infant and child mortality. For parents who see around them many child deaths, and expect a high proportion of their children to die, ensure their family survival by having more children than they would if all the children planned had a good chance of survival. This is what is called the "insurance effect" of child death. By the same token, parents in these countries would reduce their family size goals and use effective measures of fertility control if they believed that virtually all children born would reach adulthood(1).

The "child replacement" involves a deliberate decision of couples to make up the lost children and is based on the fate of their previous child bearing(9). The relationship between child survival and fertility through a replacement effect has been shown at macro level in different studies(9-11). The relationship at a micro level has not been well studied and conclusive and hence the study was undertaken.

\section{MATERIALS AND METHODS}

The study was conducted in Central Ethiopia $130 \mathrm{Kms}$ South of the Capital City Addis Ababa in a place commonly referred to as Butajira(12). The study design was a casereferent where the cases were women with number of children ever born alive (CEB) less than five. Controls were women with number of children ever born alive (CEB) greater or equal to five. The cutoff point of five was taken because the medical and obstetric risk for mothers with number of CEB greater or equal to five is significantly higher (three times) compared with those less than five (13). The Butajira Rural Health Program (BRHP) has selected nine peasant associations (PAs) out of a total of 82 PAs in the district, and one Urban dwellers association (UDA) out of four in the town. Out of the nine PAs, six PAs were selected randomly after stratifying into highland and lowland. By a lottery method three PAs from each stratum were selected. The study subjects were selected from the Butajira Rural Health Project (BRHP) surveillance system with age range from 30 to 49 . The age range was restricted as fertility was affected by age. All women aged 30-49 years with duration of marriage 10 years and above in the selected six PAs were included in the study. Sample size was calculated considering education as a major determinant of fertility using STATCALC program of EPI INFO Version 6.2.

The proportion of women who was educated among the high fertility women was considered to be $15 \%$. Minimum detectable OR of 2.0 , a $5 \%$ level of significance, a power of $80 \%$ and allocation ratio of cases to controls $\left(\mathrm{n}_{1}: \mathrm{n}_{2}\right)$ 1:4. These assumptions gave a sample of size 217 for cases and 867 for the controls.

Standardized structured questionnaire that was used in the 2000 demographic and health survey (DHS) was used so as to enable comparability of study findings. A pretest was conducted in a rural village adjacent to the study area called Dubotuto to test understand ability and answer ability of the questionnaire and to familiarize the interviewers with the instrument.

The number of ever born alive (CEB) children, which is categorized as low when CEB alive is less than 5 and high when CEB alive is greater or equal to 5 was the main dependent variable. Independent variables include socioeconomic and demographic variables, child mortality, fertility preference, and reproductive variables. Child mortality in this study refers to the death of a child and an infant inclusive.

The data collectors were recruited from the Butajira rural health project. The data collectors of the study base had prior training on data collection and have worked in the study base for about a decade. Training was given to the data collectors by the principal investigator on the method of data collection with respect to the study for two days. There were 16 data collectors and two supervisors with reliability check of 1 in 50 households. Incomplete questionnaires were filled by callbacks while on the fieldwork. The data collection was done on March/April 2001. The data were entered into EPI info version 6.2-computer program. The study got ethical clearance from the Department of Community Health and the Faculty of Medicine of Addis Ababa University.

\section{RESULTS}

A total 219 cases and 899 controls were included in the study. The majority of the study subjects were the Meskans in ethnicity (49.9\%) followed by the Selte (15.5\%) and Sodo (12.5\%). About $82.2 \%$ of the women were housewives and the remaining being petty traders, farmers and Tella (local drink) sellers (self-employed) while most of their husbands got their means of subsistence from agriculture. Muslim was the main religion $(74.1 \%)$ of the study subjects. The women among the low fertility group were better educated $(13.7 \%)$ than the women in the high fertility group (7.9\%) (Table 1).

The difference between the high and low fertility groups in relation to child death was statistically significant. History of child death was associated with higher number of children ever born alive with OR of 6.45 and $95 \% \mathrm{CI}$ between 4.62 and 9.08. The difference persisted even after controlling for socio-demographic, reproductive and birth outcome variables with OR of 7.39 and 95\%CI between 4.62 and 9.08 (Table 2). Those mothers with history of child death are likely to end up in having many children. As the number of children dead increased, there was a proportionally significant increase in the number of ever born alive children $\left(\mathrm{X}^{2}\right.$ for trend $=4.92, \mathrm{df}=4, \mathrm{P}$-value $\left.=0.02\right)$ (Table 2).

The occurrence of abortion (wanted or unwanted) and stillbirth didn't contribute for significant difference among the low and high fertility profile group. The Odds Ratio (OR) for wanted abortion was 1.35 with 95\% CI between 0.28 and 8.84 , the OR for unwanted 
abortion was 1.01 with $95 \%$ CI between 0.66 and 1.54 , and the OR for still birth is 2.47 with $95 \%$ CI between 0.93 and 7.12 (Table2).

The desire for more children currently showed a significant difference in the number of children ever born alive with the odds of desire for more children among the high fertility group was 1.63 times more than the odds of having no desire for more children among the low fertility group with $95 \%$ confidence interval between 1.13 and 2.34 (Table 3). But this difference disappeared when socio-demographic, reproductive and delivery outcomes were controlled. The number of children desired before marriage did not show significant difference among the two-fertility profile group with OR of 0.83 and $95 \%$ confidence interval between 0.00 and 5.41 (Table 3). Some of the reasons stated for desiring more children were children are wealth, children are source of help in old age, children may or may not grow, children are honour, children help to maintain posterity among other reasons (Table 4).

Table 1

Fertility level versus socio demographic variables of women in Butajira Adjusted for socio-demographic variables

\begin{tabular}{|c|c|c|c|c|c|c|}
\hline & $\begin{array}{l}\text { Low fertility } \\
(\mathrm{n}=219) \\
\text { No. }(\%)\end{array}$ & $\begin{array}{l}\text { High fertility } \\
(\mathrm{n}=899) \\
\text { No. }(\%)\end{array}$ & $\begin{array}{l}\text { Crude } 95 \% \\
\text { OR }\end{array}$ & $\mathrm{Cl}$ & $\begin{array}{l}\text { Adjusted } \\
\text { OR }\end{array}$ & $95 \% \mathrm{CI}$ \\
\hline \multicolumn{7}{|c|}{ Maternal age (years) } \\
\hline $30-34$ & $152(69.4)$ & $235(26.1)$ & 1 & & & \\
\hline $35-39$ & $27(12.3)$ & $251(27.9)$ & 0.17 & $(0.10,0.27)$ & 0.20 & $(0.12,0.35)$ \\
\hline $40-44$ & $23(10.5)$ & $249(27.7)$ & 0.14 & $(0.09,0.23)$ & 1.14 & $(0.60,2.19)$ \\
\hline $45-49$ & $17(7.8)$ & $164(18.2)$ & 0.16 & $(0.09,0.28)$ & 1.17 & $(0.61,2.23)$ \\
\hline \multicolumn{7}{|l|}{ Ethnicity } \\
\hline Meskan & $113(51.6)$ & $445(49.5)$ & 1 & & & \\
\hline Selte & $38(17.4)$ & $135(5.5)$ & 1.11 & $(0.72,1.71)$ & 0.69 & $(0.29,1.59)$ \\
\hline Sodo & $20(9.1)$ & $120(13.3)$ & 0.66 & $(0.38,1.13)$ & 0.67 & $(0.26,1.66)$ \\
\hline Mareko & $27(12.3)$ & $112(12.5)$ & 0.95 & $(0.58,1.55)$ & 0.82 & $(0.31,2.19)$ \\
\hline Dobi & $10(4.6)$ & $40(4.4)$ & 0.98 & $(0.45,2.12)$ & 0.86 & $(0.35,2.12)$ \\
\hline Others & $11(5.0)$ & $47(5.2)$ & 0.92 & $(0.44,1.91)$ & 0.46 & $(0.15,1.38)$ \\
\hline \multicolumn{7}{|l|}{ Religion } \\
\hline Muslim & $173(78.9)$ & $655(72.8)$ & 1 & & & \\
\hline Orthodox & $35(15.9)$ & $213(23.7)$ & 0.62 & $(0.41,0.94)^{*}$ & 1.43 & $(0.49,4.17)$ \\
\hline Others & $11(5.0)$ & $31(3.4)$ & 1.34 & $(0.62,2.85)$ & 6.84 & $(0.12,41.69)$ \\
\hline \multicolumn{7}{|c|}{ Educational Status } \\
\hline \multicolumn{7}{|c|}{ Cannot read and } \\
\hline Write & $189(86.3)$ & $828(92.1)$ & 1 & & & \\
\hline $\begin{array}{l}\text { Read and wi } \\
\text { and above }\end{array}$ & $30(13.7)$ & $71(7.9)$ & 1.85 & $(1.14,2.98)^{*}$ & 1.46 & $(0.77,2.78)$ \\
\hline \multicolumn{7}{|l|}{ Occupation } \\
\hline House wife & $190(86.8)$ & $770(85.7)$ & 1 & & & \\
\hline Others & $29(13.2)$ & $129(14.3)$ & 0.91 & $(0.58,1.43)$ & 0.96 & $(0.61,1.52)$ \\
\hline \multicolumn{7}{|c|}{ Income (monthly/Birr) } \\
\hline$\leq 100$ & $192(87.7)$ & $692(76.9)$ & 1 & & & \\
\hline $101-200$ & $19(8.7)$ & $145(16.1)$ & 0.47 & $(0.28,0.80)^{*}$ & 0.02 & $(0.00,7.6)$ \\
\hline$>201$ & $1(0.5)$ & $26(2.9)$ & 0.14 & $(0.01,0.96)^{*}$ & 0.04 & $(0.00,1.52)$ \\
\hline Don't know & $7(3.2)$ & $36(4.0)$ & & & & \\
\hline \multicolumn{7}{|c|}{ Residence till 12 years } \\
\hline Urban & $5(2.3)$ & $32(3.6)$ & 1 & & & \\
\hline Rural & $214(97.7)$ & $867(96.4)$ & 1.58 & $(0.58,4.67)$ & 1.69 & $(0.56,5.14)$ \\
\hline
\end{tabular}

* significant at $5 \%$

** Adjusted for socio-demographic variables 
Table 2

Fertility level versus child/infant mortality and pregnancy outcome of women in Butajira adjusted for socio-demographic, reproductive and delivery outcome variables

\begin{tabular}{|c|c|c|c|c|c|c|}
\hline & $\begin{array}{l}\text { Low fertility } \\
(\mathrm{n}=219) \\
\text { No. }(\%)\end{array}$ & $\begin{array}{l}\text { High fertility } \\
(\mathrm{n}=899) \\
\text { No. }(\%)\end{array}$ & Crude & $\begin{array}{l}95 \% \mathrm{Cl} \\
\mathrm{OR}\end{array}$ & $\begin{array}{l}\text { Adjusted } \\
\text { OR }\end{array}$ & $\begin{array}{lll}95 \% & \mathrm{Cl} & \mathrm{X}^{2} \\
& \text { for trend }\end{array}$ \\
\hline \multicolumn{7}{|c|}{$\begin{array}{l}\text { History of Child/infant } \\
\text { mortality }\end{array}$} \\
\hline No & $154(70.3)$ & $241(26.8)$ & 6.47 & $(4.62,9.08)$ & 7.39 & $(4.62,9.08)^{*}$ \\
\hline Yes & $65(29.7)$ & $658(73.2)$ & 1 & & & \\
\hline \multicolumn{7}{|c|}{ Abortion (wanted) } \\
\hline No & $217(99.1)$ & $888(98.8)$ & 1.35 & $(0.28,8.84)$ & 0.03 & \multirow[t]{2}{*}{$(0.00,8.3 \mathrm{E}+30)$} \\
\hline Yes & $2(0.9)$ & $11(1.2)$ & & & & \\
\hline \multicolumn{7}{|c|}{ Abortion (Unwanted) } \\
\hline No & $184(84.1)$ & $754(83.9)$ & 1.01 & $(0.66,1.54)$ & 1.88 & $(0.19,17.83)$ \\
\hline Yes & $35(15.9)$ & $145(16.1)$ & 1 & & & \\
\hline \multicolumn{7}{|l|}{ Still birth } \\
\hline No & 214 (977) & $850(94.5)$ & 247 & $(093,7.12)$ & 0.01 & \multirow[t]{2}{*}{$(0.00,3.1 \mathrm{E}+24)$} \\
\hline Yes & $5(2.3)$ & $49(22.5)$ & & & & \\
\hline \multicolumn{7}{|c|}{ No of children/ infant died } \\
\hline 1 & $6(2.7)$ & $9(1.0)$ & & & & \multirow{5}{*}{$4.92 *$} \\
\hline 2 & $41(4.6)$ & $127(14.1)$ & & & & \\
\hline 3 & $60(27.4)$ & $125(13.9)$ & & & & \\
\hline 4 & $41(18.7)$ & $101(11.2)$ & & & & \\
\hline$\geq 5$ & 38 (17.4) & $175(19.5)$ & & & & \\
\hline
\end{tabular}

* Significant at $5 \%$

** Adjusted for socio-demographic and reproductive variables

Table 3

Fertility level versus fertility preference of women in Butajira adjusted for socio-demographic, reproductive and delivery outcome variables

\begin{tabular}{|c|c|c|c|c|c|c|}
\hline & $\begin{array}{l}\text { Low fertility } \\
(\mathrm{n}=219) \\
\text { No. }(\%)\end{array}$ & $\begin{array}{l}\text { High fertility } \\
(\mathrm{n}=899) \\
\text { No. }(\%)\end{array}$ & $\begin{array}{l}\text { Crude } \\
\text { OR }\end{array}$ & $95 \% \mathrm{Cl}$ & $\begin{array}{l}\text { Adjusted } \\
\text { OR }\end{array}$ & $95 \%$ CI \\
\hline \multicolumn{7}{|c|}{ No. of desired Children (Before marriage) } \\
\hline$<5$ & $10(4.6)$ & $35(3.9)$ & 1 & & & \\
\hline$\geq 5$ & $157(71.7)$ & $661(73.5)$ & 0.83 & $(0.39,1.83)$ & 0.99 & $(0.00,5.40)$ \\
\hline As God Gives & $52(23.7)$, & $203(22.6)$ & 0.92 & $(0.41,2.12)$ & 0.99 & $(0.00,5.21)$ \\
\hline \multicolumn{7}{|c|}{ Desire for more children (Current) } \\
\hline No & $170(77.6)$ & $612(68.1)$ & 1.63 & $(1.13,2.34)^{*}$ & 1.49 & $(0.71,1.96)$ \\
\hline Yes & $49(22.4)$ & $287(31.9)$ & 1 & & & \\
\hline
\end{tabular}

** Adjusted for socio-demographic and reproductive variables

Table 4

Reasons given for desiring more children of women in Butajira

\begin{tabular}{lrr}
\hline Reason & No. & $(\%)$ \\
\hline Children are wealth & 38 & 11.1 \\
Children are source of help in old age & 141 & 42.0 \\
Children may or may not grow & 47 & 14.1 \\
Children are honour & 28 & 8.4 \\
Children help to maintain posterity & 82 & 24.4 \\
\hline Total & 336 & 100 \\
\hline
\end{tabular}

* The total was 336 those who desired more children 
Table 5

Fertility level versus sexual behaviour of women in Butajira adjusted for socio-demographic and reproductive variables

\begin{tabular}{|c|c|c|c|c|c|c|}
\hline Risk factor & $\begin{array}{l}\text { Low fertility } \\
(\mathrm{n}=219) \\
\text { No. }(\%)\end{array}$ & $\begin{array}{l}\text { High fertility } \\
(\mathrm{n}=899) \\
\text { No. }(\%)\end{array}$ & $\begin{array}{l}\text { Crude } \\
\text { OR }\end{array}$ & $95 \% \mathrm{Cl}$ & $\begin{array}{l}\text { Adjusted } \\
\text { OR }\end{array}$ & $95 \% \mathrm{Cl}$ \\
\hline \multicolumn{7}{|c|}{ Age at first marriage (years) } \\
\hline$<15$ & $10(4.6)$ & $87(9.7)$ & 1 & & & \\
\hline $15-19$ & 175(79.9) & $764(84.9)$ & 1.99 & $(10.98,4.17)$ & 1.68 & $(1.18,2.56)^{*}$ \\
\hline $20+$ & $34(15.5)$ & $48(5.3)$ & 6.16 & $(2.64,14.68)^{*}$ & 1.82 & $(1.24,2.83)^{*}$ \\
\hline \multicolumn{7}{|c|}{ Duration of marriage (years) } \\
\hline $10-14$ & $84(38.3)$ & $61(6.8)$ & 1 & & & \\
\hline $15+$ & 135 (61.6) & $838(93.2)$ & 0.12 & $(0.08,0.17)^{*}$ & 0.15 & $(0.12,0.32)^{*}$ \\
\hline \multicolumn{7}{|c|}{ Being in polygamous marriage } \\
\hline No & $147(67.1)$ & $583(64.8)$ & 1 & & & \\
\hline Yes & $72(32.9)$ & $316(35.1)$ & 0.90 & $(0.65,1.25)$ & 1.11 & $(0.70,1.74)$ \\
\hline \multicolumn{7}{|c|}{ Frequency of sex in days/month } \\
\hline $0-4$ & $24(10.9)$ & $84(9.3)$ & 1 & & & \\
\hline $5-10$ & $51(23.3)$ & $234(26.0)$ & 0.76 & $(0.43,1.37)$ & 2.64 & $(0.19,34.90)$ \\
\hline $11-20$ & $39(17.8)$ & $162(18.0)$ & 0.84 & $(0.46,1.55)$ & 3.36 & $(0.27,41.53)$ \\
\hline $21-30$ & $2(9.1)$ & $8(0.9)$ & 1.22 & $(0.24,5.60)$ & 4.46 & $(0.34,58.91)$ \\
\hline Not willing to tell & $103(47.0)$ & $411(45.7)$ & & & & \\
\hline \multicolumn{7}{|l|}{ Age at menarche } \\
\hline$<15$ & $42(19.2)$ & 197 (21.9) & 1 & & & \\
\hline 15- 19 & $167(76.3)$ & $682(75.8)$ & 1.15 & $(0.78,1.70)$ & 0.72 & $(0.17,3.02)$ \\
\hline $20+$ & $10(4.6)$ & $19(2.1)$ & 2.47 & $(0.99,6.10)$ & 0.41 & $(0.27,3.87)$ \\
\hline Don't know & 0 & 1 & $(0.1)$ & & & \\
\hline \multicolumn{7}{|l|}{ Age at first intercourse } \\
\hline$<15$ & $12(5.5)$ & $85(9.4)$ & 1 & & & \\
\hline $15-19$ & $174(79.5)$ & $767(85.3)$ & 1.61 & $(0.83,3.17)$ & 0.12 & $(0.03,4.56)$ \\
\hline $20+$ & $33(15.1)$ & $46(5.1)$ & 5.08 & $(2.26,11.58)^{*}$ & 0.41 & $(0.04,3.87)$ \\
\hline Don't know & 0 & $1(0.1)$ & & & & \\
\hline \multicolumn{7}{|l|}{ Age at first birth } \\
\hline$<19$ & $108(49.3)$ & $682(75.8)$ & & & & \\
\hline $20+$ & $98(44.7)$ & $214(23.8)$ & 2.89 & $(2.09,4.01)$ & 3.08 & $(2.03,4.68)^{*}$ \\
\hline Infertile & $13(5.9)$ & $0(0)$ & & & & \\
\hline Don't know & 0 & $3(0.3)$ & & & & \\
\hline \multicolumn{7}{|l|}{ Age at last birth } \\
\hline$\leq 24$ & $27(12.3)$ & $9(1.0)$ & 1 & & & \\
\hline $25-29$ & $84(38.4)$ & $87(9.7)$ & 0.30 & $(0.12,0.71)$ & 0.03 & $(0.01,0.07)$ \\
\hline $30+$ & $94(42.9)$ & $802(89.2)$ & 0.04 & $(0.02,0.08)$ & 0.11 & $(0.07,0.17)$ \\
\hline Infertile & $13(5.9)$ & 0 & & & & \\
\hline Don't know & 0 & $1(0.1)$ & & & & \\
\hline \multicolumn{7}{|c|}{ Postpartum abstinence (last birth) } \\
\hline $0-2$ & $140(63.9)$ & $637(70.9)$ & 1 & & & \\
\hline $3-5$ & $46(21.0)$ & $139(15.5)$ & 0.23 & $(0.23,0.47)^{*}$ & 0.97 & $(0.31,3.11)$ \\
\hline $6+$ & $19(8.7)$ & $56(6.2)$ & 1.56 & $(0.86,2.76)$ & 1.27 & $(0.48,3.39)$ \\
\hline Infertile & $13(5.9)$ & $0(0)$ & & & & \\
\hline Don't know & $1(0.5)$ & $67(7.5)$ & & & & \\
\hline \multicolumn{7}{|c|}{ Post abstinence (last but one birth) } \\
\hline $0-2$ & $140(63.9)$ & $637(70.9)$ & 1 & & & \\
\hline $3-5$ & $48(21.9)$ & $202(22.5)$ & 1.08 & $(0.74,1.58)$ & 2.10 & $(0.00,4.45 \mathrm{E}+52)$ \\
\hline $6+$ & $11(5.0)$ & $46(5.1)$ & 1.09 & $(0.52,2.24)$ & 1.56 & $(0.00,3.19 \mathrm{E}+52)$ \\
\hline Infertile & $13(5.9)$ & $0(0)$ & & & & \\
\hline Don't know & $7(3.2)$ & $14(1.6)$ & & & & \\
\hline \multicolumn{7}{|c|}{ Postpartum ammenorrhoea (last birth) } \\
\hline $0-6$ & $32(14.6)$ & $148(16.5)$ & 1 & & & \\
\hline $7-12$ & $45(20.5)$ & $178(19.8)$ & 1.17 & $(0.69,1.99)$ & 0.69 & $(0.25,1.92)$ \\
\hline $13-18$ & $26(11.9)$ & $112(12.5)$ & 1.07 & $(0.58,1.98)$ & 0.34 & $(0.13,1.89)$ \\
\hline $19-24$ & $71(32.4)$ & $312(34.7)$ & 1.05 & $(0.65,1.71)$ & 0.68 & $(0.25,1.87)$ \\
\hline $24+$ & $31(14.1)$ & $148(16.5)$ & 0.97 & $(0.54,1.73)$ & 0.93 & $(0.41,2.10)$ \\
\hline Infertile & $13(5.9)$ & $0(0)$ & & & & \\
\hline Don't know & $1(0.5)$ & $1(0.1)$ & & & & \\
\hline
\end{tabular}




\begin{tabular}{|c|c|c|c|c|c|c|}
\hline \multicolumn{7}{|c|}{ Postpartum ammenorrhoea (last but one birth) } \\
\hline $7-12$ & $22(10.0)$ & $116(12.9)$ & 1.02 & $(0.48,2.18)$ & 1.98 & $(0.69,5.73)$ \\
\hline $13-18$ & $36(16.4)$ & $123(13.7)$ & 1.57 & $(0.79,3.18)$ & 2.63 & $(0.98,7.09)$ \\
\hline $19-24$ & $91(41.6)$ & $418(46.5)$ & 1.17 & $(0.63,2.18)$ & 1.04 & $(0.42,2.60)$ \\
\hline $24+$ & $31(14.2)$ & $147(16.4)$ & 1.13 & $(0.56,2.31)$ & 1.33 & $(0.63,2.81)$ \\
\hline Infertile & $13(5.9)$ & 0 & & & & \\
\hline Don't know & $10(4.6)$ & $9(1.0)$ & & & & \\
\hline \multicolumn{7}{|c|}{ Breast feeding duration (last birth) } \\
\hline $0-6$ & $28(12.8)$ & $141(15.7)$ & 1 & & & \\
\hline $7-12$ & $33(15.1)$ & $162(18.0)$ & 1.03 & $(0.57,1.85)$ & 1.67 & $(0.72,3.84)$ \\
\hline $13-18$ & $14(6.4)$ & $52(5.8)$ & 1.36 & $(0.62,2.93)$ & 1.97 & $(0.88,4.39)$ \\
\hline $19-24$ & $74(33.8)$ & $297(33.0)$ & 1.25 & $(0.76,2.08)$ & 0.77 & $(0.27,2.21)$ \\
\hline $24+$ & $55(25.1)$ & $245(27.3)$ & 1.13 & $(0.67,1.92)$ & 1.04 & $(0.59,1.86)$ \\
\hline Infertile & $13(5.9)$ & 0 & & & & \\
\hline Don't know & $2(1.0)$ & $2(0.2)$ & & & & \\
\hline \multicolumn{7}{|c|}{ Breast feeding duration (last but one birth) } \\
\hline $0-6$ & $9(4.1)$ & $69(7.7)$ & & & & \\
\hline $7-12$ & $16(7.3)$ & 41 (4.6) & 2.99 & $(1.12,8.15)^{*}$ & 1.92 & $(1.30,2.80)^{*}$ \\
\hline $13-18$ & $14(6.4)$ & $36(4.0)$ & 2.98 & $(1.08,8.36)^{*}$ & 1.38 & $(1.16,1.88)^{*}$ \\
\hline$>18$ & $166(7.6)$ & 748 (83.2) & 1.74 & $(0.81,3.86)$ & 1.05 & $(0.59,1.88)$ \\
\hline Infertile & $13(5.9)$ & 0 & & & & \\
\hline Don't know & $1(0.5)$ & $5(0.5)$ & & & & \\
\hline
\end{tabular}

* Significant at $5 \%$

** Adjusted for socio-demographic and reproductive variables

Among the factors studied besides child mortality and fertility preferences, age at first marriage, age at first birth and breast-feeding duration appeared to significantly influence fertility level. The earlier age at first marriage and at first birth, the higher the fertility with OR of 1.82 and $95 \% \mathrm{CI}(1.24,2.83)$ and $3.08(2.03,4.68)$ respectively (Table 5).

Those mothers who breast-fed their child in the last but one child for more than six months had a significantly lower number of children ever born alive than mothers who breast fed below six months. Breast feeding duration of 7-12 months and 13-18 months showed significantly lower fertility with OR of 1.92 and $95 \%$ CI $(1.12,8.15)$ and OR of 1.38 with $95 \%$ CI of $(1.16$, 1.88) respectively (Table 5).

\section{DISCUSSION}

This study has attempted to look at the effects of child mortality and fertility preference on fertility status in a rural context encompassing as many confounding factors as possible. In those mothers who experienced child death the risk of having higher fertility is increased. As the number of children who died increased, the risk of having higher fertility increased proportionally. Similar results have been documented in Korea(13), and India(1). In a study done in urban India, the fear of child mortality and their own experience of the child death tended to increase the size of family even beyond what the mother considered to be ideal(1). The Korean data collected for national fertility survey indicated conclusively that infant death increase the sequential risk of child bearing across the birth order and irrespective of time, whether family planning services were available or not(13).
A study conducted in urban Addis Ababa has also shown the fertility enhancing effect of child death after controlling for variables like age at marriage, desired number of children, educational level of woman and husband and working status of women(14). There is an argument that the association between child death and number of children ever born alive works in both directions. Whichever direction the association works whether child death results in high number of CEB alive or high number of CEB alive results in child death, child death is strongly associated with high fertility status.

The role of induced and spontaneous abortion in explaining fertility differentials is insignificant. Getting information on abortion is quite difficult hence the fertility declining effect of abortion has been very difficult to quantify(15). An attempt was made in Kenya and Zimbabwe to see the impact of abortion on fertility but because of rare and unreliable statistics on induced abortion, it was not possible to see its effect(16).

Number of children desired before marriage is not significantly different between the two fertile groups. This is contrary to other studies where the desire to have lower children usually precedes the actual decline in fertility(17). Specific sex preference didn't account for fertility differential in this study. This is also contrary to other findings where boy preference exerts a significant effect on fertility $(18,19)$. Other studies indicated insignificant influence of sex preference on fertility (16,20-22).

Age at first marriage has significant bearing on the number of children ever born alive. Age at marriage is an important factor influencing fertility in countries like Ethiopia where level of contraception is very low. Similar results are documented in Nepal(23), Egypt(24) and Morocco(25). The earlier age at marriage exposes 
to an early first intercourse with a consequence to earlier age at first birth. Mothers with an earlier age at first birth are likely to end up in having many children(26).

The duration of breast-feeding showed significant difference between the two fertility profiles in the last but one child. Those mothers with a prolonged breastfeeding showed a lower fertility status. A comparative study assessing differentials of fertility in two rural areas of Bangladesh, Matlab and Teknaf showed a variation in the natural fertility of the two populations. The differences in number of children ever born alive were explained by the difference in breast-feeding practice of the two populations with median duration of 30 months for Matlab and 22 months for Teknaf(19). The demographic and health survey data of Kenya showed that the fertility declining effect of postpartum infecundabilty stood dominant over the other determinants(16).

The overall contraceptive use among the study subjects was low (1.9\%) when compared with the Ethiopian national average of $8 \%$ and also lower than the CPR for rural Ethiopia, which is $4.3 \%$ (8). Therefore, the use of contraception did not appear to have a significant effect on fertility level. In areas where the use of contraception is significantly higher like Senegal(4,27), Bangladesh(19,28), Egypt(24) and Zimbabwe(16), the fertility declining effect of contraception is significant.

Some of the events may be difficult to remember and hence the effect of recall bias and chicken-egg dilemma in some associations must be treated carefully. Among the factors considered in this childhood mortality by far stands as a powerful predictor of fertility. Measures taken to decrease childhood mortality will indirectly help in reducing fertility. Such measures would give impulse to fertility controlling programmes and hence should be further strengthened. Curbing the high child mortality through measures like better vaccination access, strengthened oral rehydration therapy and better hygiene through safe water supply is recommended. Delaying the age at first marriage and first birth through an organized women activity for women empowerment, encouraging mothers to breast-feed their child for a longer duration are recommended.

\section{ACKNOWLEDGEMENTS}

We are greatly indebted to Medical Faculty of Addis Ababa University for funding the research. We also thank the study participants.

\section{REFERENCES}

1. Saksena, D., Srivastava, J. and Lehler, E. Impact of child mortality and socio demographics attributes on family size: some data from Urban India. J. biosoc. Sci. 1984; 16:119-126.

2. Kirk, D. and Pillet, B. Fertility levels, a trend and differential in sub-Saharan Africa in the 1980's and 1990's. Studies Family Planning. 1988; 26:1-25.
3. John Hopkins University. Saving Women's lives. Population Reports 1999; 25:3-4.

4. Onuoha, N. Contributions of the proximate determinants to fertility changes in Senegal. Soc. Sci. Med. 1992; 35:13171320.

5. CSA. The 1994 Population and Housing Census of Ethiopia. Results at the country level statistical report, 1998. Office of population and housing census commission, Central Statistical authority: Addis Ababa, Ethiopia.

6. CSA. Ethiopia demographic and health survey 2001. Central Statistical authority, Addis Ababa.

7. Kaba, M. Fertility among women in rural communities around Jimma, Western Ethiopia. Ethiopia. J. Hlth. Dev. 2000; 14:117-125.

8. Berhane, Y. Women's health and reproductive outcome in rural Ethiopia. PhD dissertation, Umea University 2000.

9. Park, C., Han, S. and Choe, M. The effect of infant death on subsequent fertility in Korea and the role of family planning. Amer. J. Pub. Hlth. 1979; 69:557-565.

10. Lehler E. The Impact of child mortality on spacing by parity. A cox-regression analysis. Demography. 1984; 23:323-337.

11. Udjo, E. The effect of child survival on fertility in Zimbabwe; a micro-macro level analysis. J. Trop. Pediat. 1997; 43:255-266.

12. Shamebo, D. Epidemiology for public health research and action in a developing society the Butajira Rural Health Program in Ethiopia. Ethiop. J. Hlth Dev. 1994; 8:1-33.

13. Park, C., Han, S. and Choe, M. The effect of infant death on subsequent fertility in Korea and the role of family planning. Amer. J. Pub. Hlth. 1979; 69:557-565.

14. Dejene, N. Impacts of some socio-demographics on fertility in urban Addis Ababa: OLS and Tobit analysis. JESA. 2000; 1:49-77.

15. Bongaarts, J. A. Polulation and Development Review frame work for analyzing the proximate determinants of fertility. Population Dev. Review. 1978; 4:105-131.

16. Sabanda, A. Reproductive change in Zimbabwe and Kenya: The role of proximate determinants in recent fertility trends. Soc. Bio. 1999; 46:82-99.

17. Thomson, E., McDonald, E., and Bumpass, L. Fertility desires and fertility: hers, his and theirs. Demography. 1990; 27:579-587.

18. Silve, W. Influence of son preference on the contraceptive use and fertility of Srillankan women. J. Biosoc. Sci. 1993; 25:319-331.

19. Rahman, M. and Vanzo, J. Gender preference and birth spacing in Matlab, Bangladesh. Demography. 1995; 30:315-332.

20. Johnson, E. and Elmi, A. Polygamy and fertility in Somalia. J. Biosoc. Sci 1987; 19:49-56.

21. Arnold, F. Measuring the effect of sex preference on fertility the case of Korea. Demography. 1985; 22:280-287.

22. Das N. Sex preference and fertility behaviour: a study of recent India data. Demography. 1987; 24:517-529.

23. Aryal, R. Socio-economic and cultural differentials in age at marriage and the effect of fertility in Nepal. J. Biosoc. Sci. 1999; 23:167-178.

24. Gadalla, S., Mccarthy, J. and Kak, N. The determinants of fertility in rural Egypt: a study of menoufia and Beni-suef governorates. J. Biosoc. Sci. 1987; 19:195-207.

25. Varea, C. Marriage, age at last birth and fertility in a traditional Moroccan population. J. Biosoc. Sci. 1993; 25:1-15.

26. Riley, A. Determinants of adolescent fertility and its consequences for maternal health, with special reference to Bangladesh. Annals New York Acad. Sci. 1994; 709: 86-100.

27. Lawoyin, T. and Onadeko, M. Fertility and childbearing practices in a rural African community. West Afr. J. Med. 1997; 16:204-207.

28. Kabir, M. and Uddin. M. The effect of nuptiality, contraception and breast-feeding on fertility in Bangladesh. J. Biosoc. Sci. 1987; 19:345-350 